\title{
OS PRINCÍPIOS ÉTICOS DA DIGNIDADE HUMANA À LUZ DA DEMOCRACIA ASSOCIATIVA DE RONALD DWORKIN
}

\author{
Yasmim Salgado Santa Brígida ${ }^{1 *}$ \\ Victor Sales Pinheiro ${ }^{2 *}$
}

Resumo

Analisa-se em que medida a dignidade humana é uma exigência ética na democracia associativa. Apresenta-se a concepção de dignidade humana de Ronald Dworkin baseada nos princípios morais do valor intrínseco da vida e o da responsabilidade pessoal, inspirados na ética kantiana. Relacionam-se os institutos morais com a organização política social, em relação ao governo e ao judiciário. A pesquisa é bibliográfica qualitativa com análise das obras "Justiça para Ouriços" e "La Democracia Possible". Conclui-se ser imprescindível o fortalecimento da democracia associativa visando o respeito às exigências da dignidade humana como limite às ações do governo para a vida boa.

Palavras-chave: Democracia Associativa/Parceria; Dignidade Humana; Valor Intrínseco da Vida; Responsabilidade Pessoal; Ronald Dworkin.

\section{THE ETHICAL PRINCIPLES OF HUMAN DIGNITY IN THE LIGHT OF RONALD DWORKIN'S ASSOCIATIVE DEMOCRACY}

\begin{abstract}
It's analyzed the extent to which human dignity is an ethical requirement in associative democracy. It's presented the Ronald Dworkin's conception of human dignity based on the moral principles of the intrinsic value of life and personal responsibility, inspired by Kantian ethics. The moral institutes are related to the social political organization, in relation to the government and the judiciary. The research is qualitative bibliographic with analysis of the works "Justice for Ouriços" and "La Democracia Possible". It is concluded that the strengthening of associative democracy is essential in order to respect the demands of human dignity as a limit to government actions for the good life.
\end{abstract}

Keywords: Associative Democracy/Partnership; Human dignity; Intrinsic Value of Life; Personal responsibility; Ronald Dworkin.

\footnotetext{
${ }^{1}$ Mestranda em Direito na linha Desenvolvimento, Políticas Públicas e Direitos Humanos (CESUPA); membro dos grupos de pesquisa (CNPQ): Democracia, Poder Judiciário e Direitos Humanos (CESUPA), Teoria Pura do Direito na linha de Teorias do Direito (CESUPA), Razão Publica, Secularização e Direitos Humanos do CESUPA; membro da LAJUPA (Liga Acadêmica Jurídica do Pará- UFPA). Endereço postal: Av. Roberto Camelier, Jurunas, $n^{\circ}$. 852, 6625455; yasmimsantabrigida@ gmail.com.

2 Professor Adjunto Dr. da Universidade Federal do Pará (UFPA) e do Centro Universitário do Pará (CESUPA), na graduação e pós-graduação. Coordenador dos Grupos de Pesquisa (CNPq): "Tradição da Lei Natural" e "Razão pública, secularização e direitos humanos: casos, princípios e teorias políticas". Mestre em Filosofia pela PUC-RIO. Doutor em Filosofia pela UERJ. Endereço postal: Universidade Federal do Pará, Instituto de Ciências Jurídicas, Rua Augusto Corrêa, 1 (Núcleo Universitário), Guamá, 66075900 - Belém, PA - Brasil; vvspinheiro@yahoo.com.br.
}

Revista de Teorias da Democracia e Direitos Políticos | e-ISSN: 2525-9660 | Belém | v. 5 | n. 2 | p. 01 - 20 | Jul/Dez. 2019. 


\section{INTRODUÇÃO}

A presente pesquisa procura demonstrar em que medida a dignidade humana é uma exigência ética na democracia associativa/parceria. Com esse intuito, apresentar-se-á a concepção de dignidade humana de Ronald Dworkin baseada nos princípios morais do valor intrínseco da vida e o da responsabilidade pessoal, inspirados na ética kantiana. Conforme a ideia de princípios éticos, demonstrar-se-á o dever político de servir ao bem maior e de apoiar instituições políticas justas.

Na seguinte seção, objetiva-se demonstrar que a ética origina a moral pessoal, a qual gerará a moral política, e o direito como sendo um ramo institucional da moral política. A obrigação política cria a necessidade de um sistema democrático, que pode ser organizado de duas formas: a democracia majoritária e a associativa/parceria, as quais possuem consequências distintas na comunidade. Nesse meio tempo, o local comum para o debate precisa ser cultivado a fim de que a democracia exista. As pluralidades partidárias, sociais, econômicas e culturais exigem igualdade de impacto no debate real para que não se incorra num regime onde prevaleça a tirania de número e se excluam os direitos das minorias. Nesse viés, Dworkin defende que os princípios substanciais da dignidade humana precisam ser compartilhados, que exista um debate político efetivo onde se possa permitir a discussão do lugar da religião, dos direitos humanos, da democracia, da justiça social e do liberalismo positivo.

Apresentar-se-ão, ainda, os motivos de a democracia ser uma forma indispensável e legítima de governo por oferecer uma base comum a todos os indivíduos. Na teoria interpretativista do direito, tem-se a noção do direito como integridade, isto é, no respeito pela dignidade humana como limite para as decisões do governo sobre o futuro dessa comunidade política. O interpretativismo de Dworkin afirma que o direito e a moral são indissociáveis; o direito está para além de regras específicas promulgadas conformes práticas aceites, incluindo também os princípios que justificam moralmente essas regras promulgadas. O governo justo decorre da indivisibilidade da dignidade para possibilitar uma vida boa.

A presente pesquisa é bibliográfica de natureza qualitativa da teoria de Ronald Dworkin, na obra "Justiça para Ouriços" e "La Democracia Possible", assim como a "Fundamentação da Metafísica dos Costumes" de Kant, dentre outros artigos científicos e 
livros de autores renomados que analisam as experiências democráticas e suas consequências na prática da vida em comunidade.

\section{OS PRINCÍOS ÉTICOS DA DIGNIDADE: O VALOR INTRÍSECO DA VIDA E A RESPONSABILIDADE PESSOAL}

Para entender a dignidade humana no contexto da política institucional na teoria interpretativista de Dworkin, faz-se essencial discustir sua concepção de ética e moral. Para isso iremos demonstrar os dois princípios das exigências da dignidade para se viver bem. $\mathrm{Na}$ medida em que Dworkin deriva os seus princípios básicos, do valor intrínseco da vida e o da responsabilidade pessoal, de Immanuel Kant, demonstrar-se-á a sua concepção ética.

$\mathrm{Na}$ obra "Justiça para Ouriços", Dworkin procura encontrar a autenticidade e a integridade da moralidade, visto que os padrões morais prescrevem como se deve tratar os outros, e os padrões éticos dizem como se deve viver (DWORKIN, 2012). Segundo Dworkin, deve se pensar nos objetivos pessoais que respeite as obrigações, deveres e responsabilidades para com os outros. Tal ideia ajusta-se à moral kantiana, pois a liberdade metafísica é entendida como um ideal ético que justifica a teoria moral (DWORKIN, 2012).

O autor procura a concepção do viver bem que guie os conceitos morais e vice e versa. Assim, o viver bem não se trata apenas de ter uma vida promissora; o "viver bem"3 é diferente da "vida boa"4. O primeiro trata do esforço de criar uma vida boa condicionada à dignidade humana; já "vida boa" é a satisfação dos desejos do instinto, gostos e preferências, a qual se possa ter orgulho (DWORKIN, 2012). Ter uma vida má não significa que a pessoa não tenha vivido bem: ela pode ter arriscado muito e perdido muito (circunstância e sorte), como alguém que vive em situações de estrema pobreza; assim como uma pessoa pode ter uma vida boa e não ter vivido bem: um príncipe que teve sucesso, refinamento cultura e prazer às custas de assassinatos e traições. Dworkin explica que viver bem é viver de acordo com os padrões éticos, ou seja, é o próprio homem que cria valor para si mesmo, e não valorizar a sua dignidade simplesmente por medo da sanção social, política, nem se conformar por preguiça.

\footnotetext{
${ }^{3} \mathrm{O}$ viver bem inclui a consciência dos valores que a vida demonstra, uma análise sobre si própria (refletir sobre a vida que leva); somado a isso, a autenticidade e o reconhecimento.

${ }^{4}$ A vida boa possui impacto das influências e considerações de parâmetros - que afetam tal vida, como a cultura, educação, talentos, gostos e interesses - e limitações que impossibilitam a vida boa - doenças e incapacidades físicas (DWORKIN, 2012). As oportunidades econômicas, sociais e políticas podem ser parâmetros (estágio de desenvolvimento da sociedade) ou limitações (injustiça social).
}

Revista de Teorias da Democracia e Direitos Políticos | e-ISSN: 2525-9660 | Belém | v. 5 | n. 2 | p. 01 - 20 | Jul/Dez. 2019. 
O autor explica tais conceitos para demonstrar a importância de se ter princípios éticos que guiem a vida, os quais formam a dignidade humana: são o respeito próprio ${ }^{5}$ (do valor intrínseco da vida) e a autenticidade (da responsabilidade pessoal). Dworkin elenca dois princípios políticos que identificam os valores mais abstratos da condição humana; são princípios substanciais e gerais comuns, que se referem às duas dimensões da dignidade humana: a) valor intrínseco da vida e b) responsabilidade pessoal (DWORKIN, 2003).

O valor intrínseco da vida humana sugere a noção de igualdade em potencialidade de êxito e vida boa, ou seja, a vida de qualquer outro é objetivamente tão importante quanto a sua, decorrente da noção de auto-respeito kantiana. É a noção de que cada pessoa deve levar a sua própria vida a sério, como uma realização bem-sucedida.

O primeiro princípio da dignidade exige que uma vida humana não seja desperdiçada, visto o dever de cada pessoa levar a sua vida a sério e aproveitar a sua oportunidade de viver essa é a importância objetiva em se viver bem. Assim, criar uma vida boa (satisfazer instintos, gostos e preferências) contribui para viver bem, mas o autor se refere à vida boa a qual se possa ter orgulho de ter vivido. Essa ambição decorre do reconhecimento da responsabilidade de que viver bem significa vida boa no sentido crítico (DUTRA, 2018).

Já a responsabilidade pessoal é decidir e executar decisões fundamentais a respeito de que tipo de vida se pretende. É uma responsabilidade especial de ter um estilo coerente de vida que o próprio indivíduo aprove e cada qual deve considerar importante viver bem (DWORKIN, 2012). É o poder de escolher o projeto de vida que se pretende, liberdade, e daí decorre o dever do agir conforme a lei.

Ao se considerar a autenticidade, considera-se, simultaneamente, o respeito próprio, porque viver bem é exprimir-se procurando uma forma de vida que considere certa em suas circunstâncias, ao que se denomina caráter/estilo ${ }^{6}$ (DWORKIN, 2012), isto é, viver segundo as próprias situações e valores que se consideram adequados, desvinculado-se de meras convenções, expectativas ou exigências dos outros. O segundo princípio da dignidade exige que a pessoa seja responsável no sentido da virtude, pois só se pode tratar um ato como seu se ele decorrer de sua personalidade e do seu caráter. Assim, a pessoa será responsável pelo que

\footnotetext{
${ }^{5}$ Respeito por reconhecimento e respeito por apreciação. O primeiro é o respeito às pessoas por reconhecerem seu estatuto como pessoas; o segundo é o respeito em virtude do caráter e sucesso das pessoas. O respeito que a dignidade exige é o por reconhecimento (DWORKIN, 2012).

${ }^{6}$ Não significa originalidade, mas, sim, algo que é feito por vontade própria, inclusive seguir uma tradição.
} 
faz (DWORKIN, 2012). Não se tem uma vida autêntica se alguns proibirem opções a outros. A indignidade ocorre quando se dá a usurpação da responsabilidade pessoal.

Logo, as decisões particulares afetam a responsabilidade judicatória de cada um, assim como o caráter e o valor do desempenho na vida. Daí, é devido à responsabilidade judicatória que os atos podem ser avaliados por padrões de desempenho relacionados a questões éticas e morais (DWORKIN, 2012). Só se tem responsabilidade quando se tem a capacidade de controlar seu próprio comportamento ${ }^{7}$ - posição de comando ${ }^{8}$-, o que não ocorre nos casos de insanidade. Algumas correntes de pensamento defendem que nunca se está em posição de comando, mas se assim for considerado, nunca será possível atribuir responsabailidade de algo a alguém em hipotese nenhuma.

Nesse ínterim, Dworkin origina seus princípios de valor intrínseco e responsabilidade pessoal de Kant, que define a ética como conhecimento racional material para estudar as leis da liberdade (KANT, 2007). A ética possui tanto uma parte empírica quanto a racional, referente à Moral (metafísica dos costumes).

A metafísica dos costumes é necessária para encontrar a fonte dos princípios práticos e evitar que os costumes fiquem sujeitos à perversão (KANT, 2007). Kant, então, sugere uma análise daquilo que não é sujeito a limitações: a boa vontade, qualquer talento humano (argúcia de espírito, a capacidade de julgar, o discernimento, coragem, decisão, temperamento) ou a fortuna (riqueza, honra, bem-estar) prescindem da boa vontade que é o querer per si. Logo, a prudência, moderação de emoções/paixões, calma, reflexão fazem parte do valor íntimo de cada pessoa e devem ser somados à boa vontade.

A razão ${ }^{9}$, nesse ínterim, é uma faculdade prática para influenciar a vontade, pois essa se encontra misturada às inclinações imediatas e egoístas. Logo, uma ação tem valor moral na

\footnotetext{
${ }^{7}$ Não se tem a responsabilidade quando há manipulações químicas ou elétricas nas pessoas, ou quando se é criança, ou se possui uma doença mental.

${ }^{8}$ A posição de comando das próprias vidas é uma posição de controle. Ter a capacidade de controle é estar consciente do que enfrenta ou quando se tomam deciões formando opiniões e crenças veradeiras sobre o mundo (DWORKIN, 2012). Daí se tem a personalidade normativa referente aos desejos, ambições e convições. É normal que as pessoas (em circunstâncias normais do cotidiano) cedam a tentações, com momentos de falhas na capacidade de organizar e orientar as próprias convicções reflexivas.

${ }^{9}$ Para Kant, o homem pertence ao mundo sensível e ao mundo inteligível (racional), que permanece estável, mas aquele só consegue se conhecer devido a um conceito empírico, visto que cria representações quando é afetado pelas coisas (sensibilidade), para poder pensar (KANT, 2007). Daí a razão cria as ideias que ultrapassam a sensibilidade para o entendimento; então, as suas leis fundamentam o mundo sensível. Portanto, aplica-se a ideia
} 
máxima que a determina, na vontade/querer de ser praticada conforme o dever. Dos princípios a priori da razão derivam-se as regras práticas para a natureza humana (KANT, 2007), os conceitos e as leis, visto que as leis morais devem servir para todos os seres racionais. Então, a determinação de uma vontade conforme a lei objetiva é uma obrigação (KANT, 2007). A esse mandamento racional chama-se imperativo (dever).

Nesse sentido, o imperativo é um princípio válido a todo ser racional, é uma fórmula de identificação da relação da vontade subjetiva com uma lei objetiva da razão. Logo, o imperativo categórico se preocupa com a forma boa e o princípio bom que reside na própria ação e está ligado com a ideia de lei prática, de uma necessidade incondicionada, objetiva e geral. Seria o agir apenas segundo uma máxima tal que possa ser lei universal, dela se derivam todos os imperativos do dever. O imperativo do dever é a necessidade prática incondicionada da ação, válido para todos e por isso é lei para a vontade humana.

Para Kant, a pessoa é um fim em si mesmo, com essa ideia está o conceito do imperativo categórico agindo sobre a vontade humana. No imperativo categórico está a lei prática universal do agir considerando a humanidade, a si e a outrem, a humanidade como fim e nunca como meio (KANT, 2007).

Então, o primeiro princípio prático - objetivo - é e a universalidade da regra que a torna lei da natureza; o segundo princípio prático - subjetivo - é o sujeito racional ser fim em si mesmo (a humanidade), e o terceiro princípio prático é a ideia da vontade de todo ser racional concebida como vontade legisladora universal. Ou seja, todo indivíduo, por ter a razão para distinguir as vontades autônomas de contingências, é livre e possui obrigações para com as leis morais; se, por escolha, não agir conforme elas, terá que arcar com suas responsabilidades cientemente.

A vontade legisladora universal está no reino dos fins, onde vários seres racionais estão ligados sistematicamente por leis comuns. O homem é legislador universal (KANT, 2007), por pertencer a esse reino e estar submetido à lei que manda que cada um jamais trate o outro como meio. A moralidade é a relação da ação de acordo com a máxima universal

de liberdade com a autonomia da vontade, onde as leis são imperativos categóricos e as ações conforme esses são deveres.

Revista de Teorias da Democracia e Direitos Políticos | e-ISSN: 2525-9660 | Belém | v. 5 | n. 2 | p. 01 - 20 | Jul/Dez. 2019. 
presente em cada ser. Assim, o dever decorre da relação a que cada homem se submete, de cada auto legislador.

A dignidade, em Kant, refere-se ao valor "íntimo" e sem equivalentes (KANT, 2007), à coisa com um fim em si mesma e à moralidade - por meio da autonomia da vontade - que é o que permite o homem ser legislador universal e estar submetido a esta no reino dos fins, o que permite a humanidade ter dignidade. A liberdade pertence à atividade dos seres racionais dotados de uma vontade, por isso a moralidade serve como lei a todos. A liberdade é uma propriedade da causalidade segundo leis imutáveis, como pressuposto da vontade em todos os seres racionais.

Assim, conforme uma análise kantiana, Dworkin retira seus princípios básicos da noção de dignidade humana, onde toda a vida possui um valor objetivo: é a noção de não desprezar a importância intrínseca da vida humana, tendo ela como um fim em si mesma seguida da responsabilidade decorrente da liberdade (autonomia da vontade) em poder admirar e desejar adotar qualquer tipo de vida de forma consciente ou irreflexiva (rotineiramente). Logo, para ele, a ética trata daquilo que é bom (uma boa vida); diferentemente da moralidade, aquilo que é justo (obrigações e responsabilidades da pessoa para com as outras), relacionado com os princípios básicos para o debate decorrentes da dignidade.

A ética, portanto, está estritamente ligada ao domínio da felicidade individual, ao viver bem. Contudo, a ética individual não leva a um individualismo egoísta, pois viver bem pressupõe, necessariamente, uma vida boa. A construção da felicidade passa, necessariamente, por relações com outras pessoas. Assim, a ética está intimamente relacionada com a moral (DUTRA, 2018). Os padrões da moral determinam como se deve tratar os outros. Assim, a prática da escravidão é errada per si, mesmo que a maioria pensasse o contrário, isso é uma argumentação moral de um julgamento valorativo.

A moral implica no primeiro princípio da dignidade em função da vida ter importância objetiva, como Kant analisa, o respeito próprio é paralelo à vida de todo ser humano, a importância objetiva da vida é universal, assim como é especial por cada um possuir personalidade própria (DWORKIN, 2012). A igualdade objetiva da vida é agir de maneira a melhorar a situação das pessoas em toda parte, vendo o benefício a si e aos outros com o mesmo peso. É o valor da humanidade de ser tratada como um fim em si mesma. 
O segundo princípio da autenticidade atribui a todos a responsabilidade pessoal de agir de forma consistente com o caráter e os projetos identificados para si próprio - é o respeito próprio exigindo que trate a si mesmo com autonomia (DWORKIN, 2012), ou seja, se tem a autonomia quando o "agir" está conforme à lei moral para se servir a qualquer fim particular. A reconciliação kantiana entre autonomia e respeito oferece um universalismo diferente, porque é na capacidade das máximas kantianas de produzirem uma lei universal que se tem um fim em si mesmo. Assim, agir conforme a lei moral produz o viver bem, logo, refuta-se o determinismo causal por ser incompatível com a responsabilidade.

Nesse aspecto, o bem comum deve considerar os desafios atuais. Os desafios da desigualdade tornam tais princípios difíceis de serem respeitados. As pessoas tendem a não se interessar por opiniões opostas às que defendem, e, nos debates políticos e institucionais, encontram-se muitos ouvidos surdos para com aquilo que o outro pronuncia. $\mathrm{O}$ caminho para a democracia prescinde do debate autêntico.

A dignidade demonstra a preocupação individual, o dever de auxílio e de não causar danos para com os outros, com isso se tem o dever geral de servir ao bem maior e de apoiar instituições justas (DWORKIN, 2012).

$\mathrm{Na}$ comunidade política, a autoridade é cedida a um soberano, parlamento e concidadãos, os quais estipulam obrigações e convenções sociais que devem satisfazer a testes éticos e morais independentes. Conforme tal ideia da proteção ética aos princípios do valor intrínseco da vida e da responsabilidade pessoal, suscita-se a relação da garantia das exigências da dignidade humana dentro do ambiente político organizado na forma democrática, o que será melhor abordado na próxima seção.

\section{A PROTEÇÃO DA DIGNIDADE HUMANA NUMA DEMOCRACIA ASSOCIATIVA/DE PARCERIA}

Os princípios e as concepções éticas abordados na seção anterior são fundamentais para a discussão sobre a realidade política na comunidade. Então, os governos e os cidadãos se organizam e estipulam obrigações e convenções sociais, as quais devem satisfazer a testes éticos e morais. Conforme tal ideia, relaciona-se a garantia das exigências da dignidade humana com a democracia associativa, o debate público, as obrigações e deveres do governo político e a atitude do poder judiciário no contexto norte-americano, que possui similaridades com as demandas sociais recentes vivenciadas no Brasil. 
A obrigação política em um Estado decorre da associação política nessa comunidade. Nesse sentido, a coerção é essencial para a manutenção da ordem e da eficiência para se ter uma vida boa e se viver bem, mas a coerção também pode ameaçar a dignidade, visto conceder poder maior de um sobre outros (que devem cumprir com os castigos da desobediência). Assim, a ameaça à dignidade decorre do perigo de se aceitar o domínio de uns sobre outros por meio das ordens, situação que impacta diretamente na responsabilidade pessoal.

Logo, a obrigação política é mais rigorosa que as outras obrigações e é determinada pela estrutura constitucional, pela história, por processos legislativos e até judiciais (DWORKIN, 2012). O governo de uma comunidade política é legítimo quando preenche essas condições. A legitimidade tem a dimensão de como o governo conquistou o poder e de como ele utiliza tal poder. No entanto, a legitimidade é diferente da justiça (DWORKIN, 2012). Os governos são justos se cumprem com as respectivas responsabilidades soberanas de tratar todas as pessoas com igual preocupação e respeito.

Nenhum Estado é completamente justo, possuindo graus, mas alguns Estados satisfazem melhor a maioria das condições da dignidade. Um Estado pode ter situações paradoxais, ou seja, ser uma democracia que permita a liberdade de expressão, possuir uma supervisão judicial à constituição, policiamento e um sistema econômico que permita com que a maioria dos cidadãos prospere de forma razoável, mas, ao mesmo tempo, impor certas políticas de exclusão de minorias e adotar leis coercitivas, prejudicando a legitimidade do Estado (DWORKIN, 2012). Quando essas características, que negam os princípios da democracia, ocorrerem em demasiada quantidade, como em tiranias, ou em regimes injustos, a obrigação política desaparece, dando margem para a desobediência civil e revoluções.

As comunidades políticas são onde os cidadãos (conjunto de indivíduos) cumprem parcialmente suas obrigações políticas por meio de uma entidade artificial e coletiva através de indivíduos com papel específico para agir sozinhos em nome da comunidade. Essa relação é referente à moral política, enquanto a moral pessoal é aquilo que cada pessoa deve à outra. A moral política estuda aquilo que todas as pessoas devem aos outros quando se age em nome da pessoa coletiva (DWORKIN, 2012).

$\mathrm{Na}$ perspectiva da moral política, tem-se os direitos políticos como os deveres e obrigações coletivas da comunidade, onde os governantes usam dos “direitos" políticos para 
implementarem seus planos de ação, podendo usar de forma discriminatória tal discurso, ao defender certos interesses da coletividade que prejudicam as condições das pessoas, como as políticas de imigração mais restritivas em prol do melhor interesse de determinada comunidade.

Os direitos políticos são trunfos que seriam adequados para guiar a ação política (DWORKIN, 2012). A justificação para uma determinada política de aumento de impostos decorre da necessidade de maior segurança pública, logo, mais policiamento, mas essa necessidade não requer que haja proibições de discursos (liberdade de expressão) e prisões aleatórias de suspeitos de terrorismo (sem julgamento justo), pois os direitos políticos são trunfos. Acontece que as nações não transformam todos os direitos políticos em direitos constitucionais fundamentais. Por exemplo, nos EUA existiram direitos políticos com relação a seguros de saúde que não haviam sido legalizados.

Além da legalização, tem-se a questão dos direitos humanos que se distinguem dos políticos. Os direitos humanos não são apenas os declarados de boa-fé por uma nação, estão para além disso e só são satisfeitos quando o comportamento do governo observa as exigências dos dois princípios básicos ${ }^{10}$ da dignidade ${ }^{11}$. Quando se tem a sobreposição entre castas diferentes, ou religiões diferentes, ou etnias diferentes, visualizam-se desrespeitos pessoais como humilhações, torturas e até mesmo genocídios, os quais são violações da proteção e garantia da dignidade humana.

\footnotetext{
${ }^{10}$ Atribuir ao ator social condições de igualdade e liberdade é considerar que a dignidade do sujeito é a primeira condição de convivência dentro de um Estado Democrático. Para tanto, deve-se tomar como conceito mínimo de dignidade do ser humano a condição de cada ator social poder estruturar-se conforme escolhas pessoais de necessidades mínimas, que não precisam ser obrigatoriamente idênticas e massificadas. Segundo Sarlet, o caráter multidimensional da dignidade da pessoa humana considera sua dimensão ontológica (embora não necessariamente biológica) e sua dimensão histórico-cultural, isto é, a dignidade tem dupla dimensão (ou função) negativa e prestacional, ao que se poderia ainda agregar a igualmente dupla dimensão objetiva e subjetiva na condição de princípio e norma inauguradora de direitos fundamentais. Esses requisitos possuem como ponto de partida a própria Constituição (CARVALHO, 2010). Ao mínimo existencial aplica-se a noção de dupla função: prestacional (positiva) e defensiva (negativa), inerente aos direitos fundamentais em geral e aos direitos sociais em particular. Sarlet alega que enquanto o mínimo fisiológico constituirá as condições materiais mínimas para uma vida condigna, no sentido da proteção às necessidades de caráter existencial básico, o mínimo existencial sociocultural assegurar ao indivíduo um mínimo de inserção na vida social e cultural (relativo à essência/personalidade humana), essa é a razão pela qual prestações básicas em termos de direitos culturais estão inclusas no mínimo existencial (SARLET, 2013).

${ }^{11} \mathrm{O}$ segundo princípio da responsabilidade pessoal, que defende as liberdades (de expressão, política, de consciência e religiosa), é aplicado de modo diverso em culturas e sociedades diferentes. Isso se refere ao paternalismo do Estado. No Brasil, por exemplo, há o entendimento de que o ensino médio obrigatório é uma forma de paternalismo essencial. Logo culturas políticas diferentes possuem determinadas perspectivas do que é a responsabilidade pessoal do indivíduo a ser protegida.
}

Revista de Teorias da Democracia e Direitos Políticos | e-ISSN: 2525-9660 | Belém | v. 5 | n. 2 | p. 01 - 20 | Jul/Dez. 2019. 
Como já mencionado, existem governos que violam as exigências básicas para a garantia da dignidade. Em alguns casos, ao intimidarem, assassinarem, torturarem seus cidadãos com o intuito de silenciarem as opiniões políticas dissonantes. Em meio a isso, o direito humano a não ser torturado é paradigmático, porque a tortura reduz a vítima a um animal em troca de informações ou pela função punitiva-vingativa.

Nos Direitos Humanos internacionais, a tortura é uma violação à dignidade. A dignidade faz referência ao irredutível humano, é o que permite o homem se elevar/expressar para além das questões biológicas; é a exigência ética proibida de ser ultrapassada, onde a violência é um ato de negação do humano, para além do atentado à vida (MARTY, 2004).

Além da tortura, que fere diretamente os dois princípios da dignidade, outro exemplo é a exigência de não causar danos específicos para determinados indivíduos em prol de outros, castigando alguém que não cometeu crimes para o bem de geral (como o bode expiatório), para que não se viole o respeito objetivo da vida. Assim, o fórum adequado para discutir as controvérsias menos graves de direitos humanos são os tribunais internacionais (DWORKIN, 2012). Já situações mais graves de clara violação aos direitos humanos exigem uma intervenção militar ou econômica formal.

Dworkin trata os direitos humanos como sendo um conceito de juízo interpretativo, onde sua aplicação está sujeita a mudanças decorrentes das diferentes condições econômicas, políticas, culturais e históricas; ao mesmo tempo, esses direitos possuem um padrão abstrato e universal, representado pela noção de que a dignidade exige a igualdade da vida objetiva e da responsabilidade pessoal (DWORKIN, 2012).

As leis e políticas de uma comunidade são uma solução política, ou seja, a política fiscal, monetária, laboral, ambiental, planejamento urbano, de saúde, de transporte, são centrais para a solução política. Logo, a mudança em algum desses pontos altera a distribuição de riquezas e de oportunidades na comunidade numa mesma situação de escolhas, sorte e capacidades pessoais dos indivíduos. Por isso não se deve afirmar uma política de laissez-faire, visto que os recursos que um indivíduo possui não dependem apenas de suas escolhas pessoais, dependem, também, das do governo. A solução política que é controlada pela comunidade determina as oportunidades, conjuntos de escolhas e cada acontecimento de má sorte que pode acontecer ao indivíduo (DWORKIN, 2012).

Revista de Teorias da Democracia e Direitos Políticos | e-ISSN: 2525-9660 | Belém | v. 5 | n. 2 | p. 01 - 20 | Jul/Dez. 2019. 
Assim, não se pode apenas considerar a vontade das maiorias. O segundo princípio da dignidade $^{12}$ limita o que é considerado aceitável pela comunidade política. O ambiente ético independente se dá quando as pessoas possuem liberdades necessárias para fazerem suas escolhas independentemente das políticas que as maiorias impõem. O que se refuta, nesse sentido, é o juízo ético coletivo, visto existirem juízos éticos diferentes.

Dworkin considera a comunidade correta aquela com um governo exercido pelas pessoas certas, possuindo representantes do povo que exercem o poder coercitivo em nome da sociedade. A forma como esse governo irá se organizar e eleger seus representantes é variável, podendo-se ter eleições por maioria ou por representação proporcional.

Acontece que a política se encontra marcada por slogans, na democracia se produz, frequentemente, líderes medíocres escravos de slogans (CUNNINGHAM, 2009), como a democracia sendo governo do povo, pelo povo e para o povo. Na realidade a democracia é um conceito interpretativo, e disputado, o conceito possui um leque de significado. A concepção democrática de Ronald Dworkin tem relação com a ausência do debate real com os princípios basilares à existência de um local comum para o regime democrático.

Na obra "La Democracia Possible", Dworkin elabora seu modelo de democracia em meio à análise do modelo democrático norte-americano, onde se vivenciaram verdadeiras guerras políticas, em especial, as eleições norte-americanas de 2004. Para isso, ele se utiliza do mapa eleitoral que demonstra o contraste de cores comprovando a profunda rixa partidária entre Republicanos e Democratas. A divisão entre Kerry/Democratas (azuis) e Bush/ Republicanos (vermelhos) mostra, na realidade, a divisão entre culturas totalizantes com convicções próprias. $\mathrm{O}$ primeiro era adepto da regulação da economia, menos liberdade para os negócios, de uma política exterior com as Nações Unidas e possuía uma postura mais sofisticada; já o segundo era adepto da presença da religião nos assuntos políticos, possuía uma postura comportamental e falava com mais rudez, ressaltando as diferenças regionais.

\footnotetext{
${ }^{12} \mathrm{O}$ segundo princípio traz a lição de que as ordens políticas devem respeitar a responsabilidade pessoal e a identificação do valor em suas próprias vidas, sendo o autogoverno a forma de governo em que as pessoas governam a si mesmas. Aqui, a dignidade resta corrompida quando a maioria não participa do jogo decisório, assim como quando a minoria não participa. Essa premissa é a coluna vertebral da concepção associativa, já que se deve pensar quais direitos devem ser reservados aos cidadãos individuais, entre eles o direito de participar das decisões políticas, como vontade e como candidato, sendo os direitos constitucionais que protegem a liberdade que os indivíduos possuem para tomar suas próprias decisões éticas (CARVALHO, 2010).
} 
Nessas eleições, presenciou-se uma mistura de preferências políticas com moralidade e estética. Dworkin procura ressaltar que não é coerente afirmar que o conservadorismo moral deva ser associado com um partido político de viés liberal, visto que não existe relação lógica necessária entre a defesa da presença mais forte da religião cristã com a defesa da redução de impostos dos mais abastados ou menos políticas em prol de Direitos Humanos (DWORKIN, 2003). Um exemplo é que, nessas eleições presidenciais, nenhum dos candidatos defendia a legalização do matrimônio homossexual, mas os eleitores que eram contra votaram em Bush pelo seu slogan partidário excessivamente focado no conservadorismo moral.

Tais posições totalizantes impedem o debate decente num lugar comum, tendo-se, assim, a noção da política como um campo de batalhas, gerando o sentimento de ódio entre as oposições. O debate é "atividade em que as pessoas compartilham uma base comum integrada por princípios políticos básicos" (DWORKIN, 2003, p. 19), ou seja, o debate é ausente na vida política mundial atualmente, em especial devido ao marketing televisivo, à interferência midiática até mesmo como estratégia de governo, com campanhas focadas na linguagem corporal e na conduta dos candidatos sem o tempo para o discurso. Daí cada partido só expõe suas próprias convicções e slogans vazios.

A realidade norte-americana não se distancia da brasileira no quesito tolerância à polarização político-partidária, visto os acontecimentos de 2013, do segundo mandato da expresidente Dilma e as campanhas eleitorais das eleições de 2018. Os eleitores associaram o candidato Bolsonaro, do PSL, com os slogans de "costumes morais conservadores" enquanto que a sua agenda era, na realidade, liberal, fato que não deve ser confundido segundo a teoria de Dworkin, não são associações lógicas necessárias, e nem mesmo coerentes, visto que a defesa de diretos sociais por partidos políticos, no Brasil, surgiu impulsionada por atividades sociais para a comunidade promovidas por igrejas cristãs. Um exemplo é o grupo defensor da reforma agrária, MST.

Democracia saudável inclui o consenso pautado na cultura de debate, ou seja, este precisa ser travado na democracia para que ela funcione positivamente, visto possuir pluralidades partidárias, sociais, econômicas, culturais e evitar que as divisões profundas e enraizadas impeçam o debate real, ocasionando a tirania de número que exclui a participação da minoria na vida política.

Revista de Teorias da Democracia e Direitos Políticos | e-ISSN: 2525-9660 | Belém | v. 5 | n. 2 | p. 01 - 20 | Jul/Dez. 2019. 
Nesse viés, Dworkin demonstra que os princípios substanciais já mencionados precisam ser compartilhados para se ter um debate político digno, que possa permitir a discussão do lugar da religião, dos direitos humanos, de democracia, de justiça social. O autor sugere o liberalismo positivo para os norte-americanos, que se trata de "revitalizar a dimensão argumentativa da política" (DWORKIN, 2003, p. 23).

A Democracia é uma forma indispensável e legítima de governo por oferecer uma base comum a todos, logo é importante que o sistema democrático se preserve. Na sua concepção de democracia, Dworkin enumera dois modelos democráticos: a concepção majoritária e a de parceria (DWORKIN, 2012).

A primeira corrente, da democracia majoritária, considera que as pessoas se governam quando a maioria conserva o poder político. No governo representativo com eleições frequentes, as leis e políticas da comunidade são as da maioria das pessoas, mas de forma processual. Já a concepção da democracia Associativa/Parceria se divide em relação à política, onde cada um se governa estando associado a uma empresa coletiva. Assim, as decisões da maioria só são democráticas se protegerem a condição e os interesses de cada um (DWORKIN, 2003). A corrente Associativa/Parceria permite o respeito e preocupações iguais a todos os parceiros, visto que a obrigação não é apenas de obediência às leis, mas de o fazer segundo as exigências da dignidade de cada um. Essa concepção cultiva um aspecto substantivo da legitimidade democrática.

A Corrente Majoritária possui falhas significativas. A Corrente Associativa/Parceria procura corrigir as questões de igualdade de consideração somada com o autogoverno. A igualdade política da democracia de parceria não é matemática, mas sim em atitudes, visto um líder político, um bilionário, uma estrela pop, ou um herói nacional não têm o mesmo impacto político que a maioria da população de desconhecidos. Assim sendo, ministros, parlamentares, políticos ${ }^{13}$ possuem muito mais impacto imediato na lei e na política que um voto de um cidadão comum (DWORKIN, 2012).

Isso impacta na função do judiciário no regime democrático, pois os juízes, na concepção majoritária, devem proteger o interesse do povo, salvaguardando a liberdade de

\footnotetext{
${ }^{13}$ Os quais, depois de eleitos, podem servir a seus interesses sem se preocuparem com a opinião popular. Isso acontece em especial quando procuram garantir uma reeleição, visto precisarem agradar os grandes contribuintes, que possuem interesses bem distintos do que a população demanda.
} 
expressão e de imprensa de corrupções, mas a concepção majoritária desconfia do poder judicial e não considera que este possa anular o efeito de uma lei defendida pelas maiorias, como é o caso da pena de morte nos EUA. Nesse caso, nega-se a liberdade positiva à dignidade dos cidadãos, as maiorias nem sempre são equitativas.

A Constituição americana não se baseia no simples governo da vontade da maioria; as garantias fundamentais têm como objetivo precípuo a proteção dos indivíduos frente o interesse comum. Nesse sentido, o controle de constitucionalidade é uma ferramenta para controlar a vontade das maiorias, rechaçando as decisões dos outros setores do governo que ofendam a moralidade política. Logo, o ganho para as minorias é maior em um sistema de revisão judicial do que em decisões legislativas (VERBICARO; FADEL, 2018). A questão é saber como os juízes podem interpretar o diploma constitucional. A neutralidade axiológica sobre essa interpretação não é possível, posto que, ao interpretar o texto constitucional, o intérprete realiza uma leitura moral e é importante que assim seja para que se garanta o respeito à dignidade humana.

A teoria interpretativista do direito busca estruturar a teoria do direito como integridade que implica no respeito pela dignidade humana, a qual limita ${ }^{14}$ as decisões do governo sobre o futuro dessa comunidade política. Dworkin concebe os direitos como um ideal político a ser perseguido, isto é, estruturar uma sociedade que conceda valor aos indivíduos e se comprometa com um sistema justo e imparcial ao garantir a liberdade, igualdade, dignidade, direitos humanos, estado laico e tolerante baseados no liberalismo igualitário e no individualismo ético (VERBICARO; FADEL, 2018).

Outra observação sobre o governo das maiorias não ser equitativo é com relação ao voto. Por exemplo, nos EUA existem resquícios da discriminação racial, como o estado de Ilinóis exigir aos seus eleitores a apresentação de uma carta de condução (DWORKIN, 2012), isso dificulta o voto das pessoas mais pobres por não possuírem tais documentos. Além de que os governos representativos são ameaças ao impacto igual porque os governantes possuem um poder de influência incomparavelmente maior do que de qualquer cidadão.

\footnotetext{
${ }^{14}$ Nesse sentido, o pressuposto da dignidade enquanto regulador das ações dos indivíduos e do Estado exige que a comunidade lance mão de qualquer recurso necessário para assegurá-lo. No caso do presidiário, mesmo que a pessoa seja privada de liberdades (limitação da autonomia), isso não autoriza o tratamento que comprometa sua condição de dignidade ao impor tortura, trabalho escravo, privação de alimentação, assistência jurídica e alojamento com mínimo de infraestrutura (BARBOSA; COSTA, 2016).
} 
Nos casos da democracia associativa/parceria, o escrutínio judicial reforça a legitimidade do governo por proteger a independência ética da minoria, além de reforçar o direito moral da maioria em outras questões (DWORKIN, 2012). A democracia não está dissociada do restante da moralidade política ao buscar uma teoria da igualdade associativa para que se possa chegar à conclusão do que é ou não uma decisão democrática (CARVALHO, 2010). A Constituição Americana limita as maiorias, por isso não se pode dizer que a democracia norte-americana seja unicamente majoritária.

Nos EUA, os conservadores acusavam os juízes de inventar novos direitos atuando com valores pessoais, criando direitos fundamentais e usurpando a função do parlamento, porém, anos antes, os conservadores defenderam a corrente associativa em favor da propriedade privada (DWORKIN, 2003). Assim, resta comprovado que o discurso da natureza democrática varia conforme o jogo de conveniência.

As nomeações de juízes nos EUA são eventos televisivos, com grandes consequências para o Presidente e os Senadores; o público americano possui mais influência sobre essa escolha que as autoridades competentes para a situação. Nesse contexto, está o perigo de permitir um conjunto de juízes com as mesmas ideias, os quais podem anular leis populares, comprometer políticas públicas e alterar instituições e processos eleitorais, visto que podem cometer erros graves. O poder judiciário deve aumentar a legitimidade geral, deixar com que a sociedade decida sobre a liberdade negativa e positiva, a distribuição justa de recursos e oportunidades, isto é, independência do poder judiciário e a obediência do mesmo à Constituição e ao Estado de direito. Em vista disso, Dworkin propõe, aos juízes do Supremo, limites de tempo de mandato.

Ao estudar as formas de governo, deve-se enumerar as vantagens de determinada forma de governo. No caso, as vantagens de uma democracia se dá pela liberdade de expressão, com uma imprensa livre que desmascare corrupções generalizadas de tiranias; além de evitarem governos que governem para o interesse pessoal, como em ditaduras; as democracias melhoram a estabilidade política, permitindo que cada grupo de uma comunidade política com um eleitorado instruído faça trocas e alianças políticas; protegem a liberdade política, a liberdade econômica e o Estado de direito essenciais para o desenvolvimento da nação (DWORKIN, 2012). Esse modelo de organização social permite que haja a participação das pessoas, o que é uma exigência da dignidade.

Revista de Teorias da Democracia e Direitos Políticos | e-ISSN: 2525-9660 | Belém | v. 5 | n. 2 | p. 01 - 20 | Jul/Dez. 2019. 
O direito é feito por seres humanos por meio de decisões contingentes e vários tipos de práticas (DWORKIN, 2012). O interpretativismo de Dworkin nega que o direito e a moral sejam sistemas totalmente independentes, o direito inclui não apenas regras específicas promulgadas conformes práticas aceites, mas também princípios que mostram a melhor justificação moral para essas regras promulgadas. O direito, então, faz parte da moral política.

O autor finaliza a sua obra com uma analogia à estrutura de uma árvore, onde a moral pessoal decorre da ética, e a moral política decorre da pessoal, o direito é apenas um ramo institucional da moral política (DWORKIN, 2012). A dignidade é indivisível (DWORKIN, 2012). O governo deve tratar aos seus cidadãos com respeito iguais, a justiça expande a liberdade, o governo justo decorre da dignidade e visa a dignidade para possibilitar uma vida boa.

Em meio a tudo isso, Dworkin se pergunta se os EUA têm um sistema político com debate autêntico, visto que em uma democracia associativa/parceira deveria ter. $\mathrm{O}$ autor se convence da ausência do debate pela análise sócio- econômica da população, que é carente de informação, tempo e capacidade para uma vida política ativa ideal, a consequência disso na política é a produção de campanhas específicas para um eleitorado ignorante, sem precisões de informações, e favorecimentos de financiamentos de campanhas (DWORKIN, 2003), visto a necessidade do marketing excessivo que prescinde de financiamento daqueles que pedem em troca de cargos públicos. A margem de análise da política norte-americana não é isolada no continente americano, isso equivale para o Brasil onde mentiras e difamações em propagandas eleitorais são estratégias eleitorais da oposição como entretenimento.

Assim, Dworkin considera possível o debate político para uma democracia associativa se houverem mudanças como na educação, com cursos de política contemporânea no ensino médio; nas eleições, com a mudança no financiamento de campanhas, representação e procedimento de votação; além, da reforma na Constituição com a previsão de limites ao tempo de mandato dos juízes da Suprema Corte (DWORKIN, 2003).

Portanto, a teoria democrática a partir da concepção associativa de Dworkin busca a promoção dos direitos de minorias ao conceber os direitos humanos como trunfos da moral política. Para garantir a efetividade das exigências da dignidade humana as instituições políticas e jurídicas possuem obrigações especiais, o Estado é representado por suas 
instituições políticas e jurídicas que devem garantir seu papel pautado na justiça para tornar possível a vida boa aos membros da comunidade.

\section{CONCLUSÃO}

Conforme ficou demonstrado, a comunidade política, através das autoridades competentes, cria obrigações que devem satisfazer a testes éticos. Dworkin observa que a legitimidade de uma organização política possui dois momentos, o de conquista de poder e no exercício desse poder, mas para isso, os governos também precisam ser justos cumprindo com as respectivas responsabilidades de tratar todas as pessoas com igual preocupação e respeito. O autor constata que nenhum Estado é completamente justo, para corrigir tais situações existem mecanismo que auxiliam na garantia dos requisitos da dignidade humana, como a supervisão judicial à constituição. Essas questões se referente à moral política, àquilo que as pessoas devem aos outros quando se age em nome da pessoa coletiva.

$\mathrm{Na}$ perspectiva, que este artigo apresentou, da moral política, tem-se os direitos políticos como os deveres e obrigações coletivas da comunidade, são trunfos guias a ação política, eles funcionam como limites críticos a ação dos representantes do povo e do Estado. Restou-se comprovado que os direitos humanos estão além dos direitos políticos declarados e positivados em cartas e documentos de direitos humanos, dessa perspectiva se conclui que tais direitos são satisfeitos quando o governo se compromete a observar as exigências dos princípios básicos a dignidade: o valor intrínseco da vida e o da responsabilidade pessoal.

Destarte, uma democracia saudável necessita da cultura do debate para se chegar a um consenso. O debate é essencial para o funcionamento da democracia, visto as pluralidades sócio- culturais, econômicas e partidárias. A melhor concepção de democracia para Dworkin é a Associativa/ Parceria, pautada na ideia de que cada indivíduo se governa estando associados a uma empresa coletiva, nessa forma de organização as decisões da maioria só são democráticas se protegerem a condição e os interesses de cada membro da associação. A corrente Associativa/Parceria possui a vantagem de permitir o respeito igual a todos os membros (igualdade de impacto), inclusive de minorias, essa noção busca corrigir as falhas da corrente majoritária ao estabelecer critérios substantivos à legitimidade democrática.

Nesse sentido, Dworkin considera o controle de constitucionalidade como uma ferramenta para controlar a vontade das maiorias, o judiciário como poder contra- majoritário 
é apropriado para fazer valer o sistema de freios e contra pessoas ao rechaçar as decisões que ofenderem a moralidade política, logo, as minorias estariam melhor protegidas em um sistema de revisão judicial, a cautela é saber até onde os juízes podem interpretar o diploma constitucional. $\mathrm{O}$ autor defende que a neutralidade axiológica do judiciário é impossível e indesejável visto que a interpretação do texto constitucional exige uma leitura moral em respeito à dignidade humana.

Por fim, este artigo demonstrou que Dworkin concebe os direitos humanos como um ideal político a ser perseguido e nega a separação incomunicável entre o direito e a moral, justamente por esses serem trunfos da moralidade política. O direito inclui o somatório de regras e princípios como justificação moral para as regras válidas. Logo os princípios éticos da dignidade humana, traduzidos por Dworkin como o valor intrínseco da vida e o da responsabilidade pessoal, são os fundamentos dos direitos humanos na melhor forma de democracia a ser posta em prática, a democracia associativa.

\section{REFERÊNCIAS}

ABRANCHES, Sérgio Henrique. Presidencialismo de Coalizão: raízes e evolução do modelo político brasileiro. $1^{\circ}$ Edição. São Paulo: Companhia das Letras, 2018.

BARBOSA, Evandro; COSTA, Thaís Cristina Alves. A concepção de dignidade humana em Ronald Dworkin: um problema de ética prática. Revista de Filosofia. v.13, n.1º jun, 2016.

CARVALHO, Cassiana Alvina. Democracia associativa: a proposta de Dworkin ao ambiente multicultural. Anais do XIX Encontro Nacional do CONPEDI, Fortaleza - CE, 2010.

CUNNINGHAM, Fank. Teorias da Democracia: uma introdução crítica. Tradução Delmar José Volpato Dutra. Porto Alegre: Artmed, 2009, p. 286.

DUTRA, Elder Gomes. A ética e a moral em Ronald Dworkin: um breve estudo do que se entende por bem viver e ter uma vida boa. Revista Pensamento Jurídico. São Paulo. v. $12, \mathrm{n}^{\circ}$ 2, jul./dez. 2018.

DWORKIN, Ronald. Justiça para Ouriços. $1^{\circ}$ edição. Coimbra: Almedina, 2012.

DWORKIN, Ronald. La Democracia Posible: principios para un nuevo debate político. Barcelona: Paidós, 2003.

KANT, Immanuel. Fundamentação da Metafísica dos Costumes. Tradução de Paulo Quintela. Lisboa, Portugal: Edições 70, 2007, p. 120.

Revista de Teorias da Democracia e Direitos Políticos | e-ISSN: 2525-9660 | Belém | v. 5 | n. 2 | p. 01 - 20 | Jul/Dez. 2019. 
MARTY, Mireille Delmas. Por um direito comum. $1^{\text {a }}$ edição. São Paulo: Martins Fontes, 2004, p. 306.

SARLET, Ingo Wolfgang. Prestação jurisdicional, dignidade (da pessoa) humana, mínimo existencial e justiça constitucional: algumas aproximações e alguns desafios. Revista CEJUR /TJSC, v. 1, n. 1, p. 29-44, 2013.

TOCQUEVILLE, Alexis de. A democracia na América. Coleção folha: livros que mudaram o mundo, v.16. Tradução de Neil Ribeiro da Silva. $1^{\circ}$ edição. São Paulo: Folha de São Paulo, 2010.

VERBICARO, Loiane Prado; FADEL, Anna Laura Maneschy. O modelo de democracia à luz da teoria de Ronald Dworkin. Revista Jurídica. Curitiba, v. 03, nº. 52, p. 248-274, 2018.

VIEIRA, Oscar Vilhena. A Batalha dos Poderes: da transição democrática ao mal-estar constitucional. São Paulo: Companhia das Letras, 2018. 